\title{
Intellectual Property and Criminal Law: Recent Trends
}

\author{
Denis Aleksandrovich Zvyagintsev, Alexander Yurievich Larin, Olga Borisovna Shelonina
}

\begin{abstract}
This article analyzes the significance of criminal liability imposed on individuals in case of violating intellectual rights. The research dwells on the role of various sectoral norms, including criminal law, in the inter-sectoral institute of intellectual property. Criminal law is considered as a component in the current development of intellectual property institute. The authors criticize some negative views on the criminal protection of intellectual rights. They also substantiate the general positive influence of criminal protection on the development of any social sphere, including the sphere of intellectual property.

Keywords: intellectual property, limitations of intellectual rights, intellectual deliverables, development trends, criminal law, criminal and legal protection.
\end{abstract}

\section{INTRODUCTION}

While scientists pay special attention to innovative processes in society and state and the necessity of such innovations, the development of intellectual property institute naturally gives rise to the corresponding discourse and generates new viewpoints on the above-mentioned development. Considering the development of intellectual property, it is necessary to proceed from the fact that this legal institute is complex and interdisciplinary. Its interdisciplinary nature implies that intellectual rights are enshrined in various acts, interconnected by a common object of regulation, affect a variety of aspects and problems of relevant social relations. The interdisciplinary nature of intellectual property institute is a common legal phenomenon since "... the system of law implies interdisciplinary (functional, structural, etc.) connections, as well as the integration of different branches. The basis of such interaction is the unity of private and public principles in the legal regulation of social relations" [1].

\section{PROPOSED METHODOLOGY}

A comprehensive study of the legislative regulation, role and importance of criminal liability in the field of intellectual property violations involves the use of various cognitive methods corresponding to the diversity of legal reality. We used dialectical, formal-logical, comparative-legal, specific historical, inductive and deductive methods, systematic approach, analysis and synthesis. In addition, we realized the principle of unified historical and logical methods of analysis that cover the phenomenon under study in all its forms.

Revised Manuscript Received on November 15, 2019

Denis Aleksandrovich Zvyagintsev, Russian State Academy of Intellectual Property, Moscow, Russia.

Alexander Yurievich Larin, Russian State Academy of Intellectual Property, Moscow, Russia.

Olga Borisovna Shelonina, Russian State Academy of Intellectual Property, Moscow, Russia.

\section{RESULTS ANALYSIS}

"Different sectoral legal regimes" in relation to intellectual property can be regarded in the following way. First of all, these relations are governed by civil law: legislators determine types of intellectual deliverables and means of individualization, their civil law regimes, ways and forms of using and managing them, personal non-property relations, civil law remedies in case of intellectual property violations.

Norms of administrative law regulate activities of the federal executive body in the process of providing legal protection, conducting registration, exercising control and supervision if there is such a need by virtue of express reference of the law.

Norms of financial and tax law control the payment of fees, the distribution and expenditure of funds allocated to obtain protectable intellectual deliverables, the payment of royalties, taxation of transactions with intellectual rights and other relations in this sphere.

Norms of criminal law aim to protect the legality of ownership, use and disposal of intellectual deliverables and intellectual rights. These norms are applied when the violation of intellectual rights can be considered as a criminal act due to the amount of damage caused by such illegal activities, losses incurred by owners, loss of profit and the copyright holder's moral costs.

Since norms of intellectual property protection belong to various branches of law, it complicates and enriches their research considering the relevant problems of relations through the diversity of their legal regulation and protection. Like many others, multivariate "manifestations of the same social relations require different sectoral legal regulatory regimes for their classification and normal functioning" [2]. Relations in the field of intellectual property are so diverse that the study of some basic civil law regime cannot cover all peculiarities of these legal relations. The development of the civil institute of intellectual property is connected with norms of criminal law, which lets scholars study criminal law in the genesis of this institute.

Criminal law in the sphere of intellectual property has a long history of legal protection and law enforcement in Russia and foreign countries. In general, it can be reasonably argued that components of the criminal justice system in the institute of intellectual property is an established practice of lawmaking and law enforcement. Despite this widely recognized practice, some scientists believe that criminal law in the field of intellectual property in economic (market) conditions is a factor hindering the development and dynamics of the economy. 


\section{Intellectual Property and Criminal Law: Recent Trends}

While studying the institute of intellectual property at the present stage, scientists face groundless allegations about the negative role of the "excessive" legal regulation in this sphere, in general, and criminal law measures, in particular. Similar viewpoints are expressed at the highest and most authoritative expert level. For example, Paul Krugman, the Nobel Prize-winning economist, shares this opinion.

Criticizing the Trans-Pacific Partnership (TPP) preferential trade agreement (in 2016, twelve countries (Australia, Brunei, Canada, Chile, Japan, Malaysia, Mexico, New Zealand, Peru, Singapore, Vietnam, and the United States) signed a preferential trade agreement aimed at eliminating trade barriers and establishing unified rules in the sphere of ecology, investment disputes and intellectual property; the agreement embraces not only developed countries but also developing economies; the United States is the largest beneficiary of the TTP agreement) "... Paul Krugman expressed concern that the TPP would tighten patent laws and allow corporations, including large pharmaceutical companies and Hollywood, to get preferences from consumers, while people in developing countries will not have access to medicines" [3]. In this case, Paul Krugman expressed the long-discussed idea that "patent legislation" (the "patent legislation" term is used in a general sense defining the existing legal acts in the sphere of intellectual property) is a factor hindering innovations. Furthermore, patent law is beneficial only for large entities that can afford a greater amount of patented objects, efficient and flexible patent policies, which ultimately blocks markets for mediumand small-scale producers and suppliers.

Similar concerns are also expressed in connection with criminal law in the field of intellectual property. Thus, the Russian Venture Company has conducted an in-depth and comprehensive study of the main development trends of intellectual property rights in the modern world and provided some opinions formulated by a number of economists from Canada and Australia. Criticizing the TTP provisions that determine the mandatory criminal liability for the violation of intellectual property rights (for those participating countries that do not have such instruments of legal pressure), they believe that "... the mandatory criminal liability for the violation of intellectual property rights, ... and the extension of their protection terms will delay the entry of generic drug-makers into the market" [4].

The idea of limiting the "legal monopoly" inherent in norms of intellectual property institute has been expressed multiple times. Forms and methods of restricting intellectual property rights are discussed in different ways and are based on a variety of arguments. Some of them are demonstrated in the example above. At the same time, the absence of direct cause-and-effect relations in the arguments expressed by "experts from Canada and Australia" (and not only by them) is an independent trend in modern discussions.

This article is concerned with the statement that "the introduction of mandatory criminal liability" can "delay the entry of some product into the market". It is possible to rephrase the question: "Can harsher liability (punishment) based on criminal law instruments delay the development of some sphere or eliminate something from this sphere?". To answer this question, it is sufficient to cite generally accepted views on the role, goals and objectives of criminal liability.

\section{DISCUSSION}

The establishment of criminal liability measures was originally defined as an incentive for social behavior and a basis for choosing some behavioral pattern through the prohibition of clearly negative activities causing harm to society [5]. Criminal liability performs a control function in a large toolkit of social and legal control. The attitude to criminal law depends on the attitude of a person or a social group to the system of social values protected by criminal law, capabilities and abilities of actors in social relations to a selective approach to the above-mentioned values. Therefore, criminal liability for acts that harm these values, the development of relations in certain spheres of public life and society as a whole should be considered in this context.

The social and legal significance of criminal law embracing criminal (illegal, undesirable, harmful to society) acts, the balance of social and personal interests, the social activity of individuals and groups, the assessment of damage, should be considered with due regard to objectives and expediency of criminal law in general. These objectives are "identified within the framework of the activity approach to criminal law which regards it as an organized and institutionalized social activity. The expediency of criminal law is associated with the recognition of a single subject of criminal law (state). Objectives of criminal law are hierarchical and based on the main objective that determines the rest of them" [6].

The main objective of criminal law stated above is defined by the provision of the basic, fundamental constitutional "... obligation of the state formulated in Article 2 of the Constitution of the Russian Federation to the extent that is established by the subject of criminal law" [6]. It is an obvious and recognized provision, an axiom that the state ensures "the recognition, observance and protection of rights and freedoms of a person and citizen ..." through criminal law [7, 8].

If someone finds measures of criminal liability too harsh "in principle", they should consider the compensatory practice of their application. "Excessively harsh" criminal liability for the violation of intellectual property rights can be compensated at the court's discretion in a particular case and even be left unsatisfied if the court concludes that the copyright holder abuses their rights referring to a formal violation that did not cause any significant losses [9].

\section{CONCLUSION}

Thus, the majority of previous and current studies on the social function of criminal liability give a negative response to the question: "Can harsher liability (punishment) based on criminal law instruments delay the development of some sphere or eliminate something from this sphere?". Criminal liability measures are established for the violation of rules determining the development of the chosen sphere. Violations of generally accepted (therefore, protected by criminal law) rules in the social sphere hinder its development rather than one's responsibility for these violations.

We can surely state that negative viewpoints on harsher responsibility for the violation

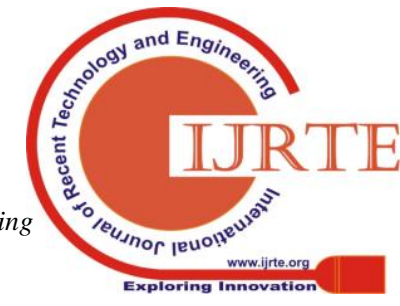


of intellectual property rights through the establishment of criminal liability cannot be substantiated. Thus, the target audience can be confused by cause-and-effect relations in the development of intellectual property institute, which forms the negative social perception and evaluation of criminal law instruments.

\section{REFERENCES}

1. M.V. Lushnikova, "Mezhotraslevye svyazi trudovogo prava: teoriya i praktika" [Intersectoral connections of labor law: theory and practice], Vestnik YarGU. Seriya Gumanitarnye nauki, vol. 3(41), 2017, p. 50.

2. V.S. Prokhorov, N.M. Kropachev, A.N. Tarbagaev, "Mekhanizm ugolovno-pravovogo regulirovaniya" [Legal and criminal regulation], Krasnoyarsk, Russia, 1989, pp. 31-32.

3. P. Krugman, "Trade and Trust", The New York Times, May 22, 2015. Available:

https://www.nytimes.com/2015/05/22/opinion/paul-krugman-trade-and -trust.html

4. G.A. Akhmedov, E.A. Voinikanis, K.D. Glazunova, N.V. Zaichenko, I.K. Knyaginina, I.A. Koroleva, Yu.A. Lipatova, K.S. Mityagin, V.R. Smirnova, K.B. Leontev, M.I. Evdokimova, V.S. Savina, A.V. Gurko, "Osnovnye tendentsii razvitiya prava intellektualnoi sobstvennosti $\mathrm{v}$ sovremennom mire, $v$ tom chisle novye obekty intellektualnykh prav i globalnaya zashchita" [Basic trends in the development of intellectual property rights in the modern world, including new objects of intellectual property rights and their global protection]. Moscow, Russia, 2017, p. 48.

5. Ugolovnyi kodeks Rossiiskoi Federatsii ot 13.06.1996 № 63-FZ (red. ot 21.10.2018) [The Criminal Code of the Russian Federation of June 13, 1996 No. 63-FZ (revised on October 21, 2018)]. (n. d.). Available: http://kremlin.ru/acts/bank/9555

6. S.Yu. Timokhin, "Funktsii, zadachi i tseli ugolovnogo prava: problemy sootnosheniya" [Functions, objectives and tasks of criminal law: correlation problems]. Vladivostok, Russia, 2002, p. 8.

7. Konstitutsiya Rossiiskoi Federatsii [The Constitution of the Russian Federation] (adopted by nation-wide voting on December 12, 1993) (with alterations made by the following amendment acts of December 30, 2008 No. 6-FKZ, of December 30, 2008 No. 7-FKZ, of February 5, 2014 No. 2-FKZ, of July 21, 2014 No. 11-FKZ) Available: http://kremlin.ru/acts/constitution

8. SZ RF [The Russian Federation Code], August 4, 2014, No. 31, Article 4398. Article 2. Available: http://www.szrf.ru/szrf/index.phtml?md=0

9. N. Voznesenskii, Yu. Gnusina, "Vozmozhno li ogranichenie rasporyazheniya rezultatami intellektualnoi deyatelnosti normami antimonopolnogo prava?" [Is it possible to limit the use of intellectual deliverables by antitrust law?], Korporativnyi yurist, vol. 6, 2012, pp. 127-128. 